\title{
Assessing the Efficacy of Broad-Spectrum Antibiotics in Controlling Bacterial Contamination in the In Vitro Micropropagation of Ginger (Zingiber officinale Rosc)
}

\author{
Selam Tewelde, ${ }^{1}$ Subban Patharajan, ${ }^{2}$ Zenebe Teka, ${ }^{2}$ and Desta Berhe Sbhatu $\mathbb{D}^{3}$ \\ ${ }^{1}$ Tigrai Biotechnology Center Pvt. Ltd. Co., Mekelle, Ethiopia \\ ${ }^{2}$ Aksum University, P.O. Box 1010, Aksum, Ethiopia \\ ${ }^{3}$ Mekelle University, P.O. Box 1632/231, Mekelle, Ethiopia
}

Correspondence should be addressed to Desta Berhe Sbhatu; desta.sbhatu@mu.edu.et

Received 6 December 2019; Accepted 7 April 2020; Published 13 June 2020

Academic Editor: Adriana Greco

Copyright ( 2020 Selam Tewelde et al. This is an open access article distributed under the Creative Commons Attribution License, which permits unrestricted use, distribution, and reproduction in any medium, provided the original work is properly cited.

Ginger (Zingiber officinale Rosc) (Zingiberaceae) is a livelihood and commercial crop in Ethiopia. But, the availability of clean and healthy planting materials has become a problem due to wilt disease, caused by Ralstonia solanacearum Biovar 3 Race 4 . This problem obliged growers to seek for tens of millions of vigorous and disease-free planting materials very quickly via in vitro micropropagation of shoot tip explants. For this purpose, protocols of sterilizing shoot tip explants and controlling bacterial contamination of one Ethiopian ginger cultivar called Deribo were tested. Hence, this article reports the finding of a study that aimed at testing the (a) effectiveness of three sterilization agents, namely, $0.25 \% \mathrm{w} / \mathrm{v}$ RBK (composed of ridomile, bayleton, and kocide at $1: 1: 1$ ratio), $0.50 \% \mathrm{v} / \mathrm{v} \mathrm{NaOCl}$, and $70 \% \mathrm{v} / \mathrm{v}$ ethanol at three different treatment times in combination with $0.25 \% \mathrm{HgCl}_{2}$; (b) efficacy of four broad-spectrum antibiotics and their combinations in controlling bacterial contaminants of ginger shoot tip explants and in vitro micropropagation media; and (c) effects of the antibiotics on the shooting performances of the explants of the cultivar. A $0.50 \% \mathrm{v} / \mathrm{v} \mathrm{NaOCl}$ at exposure time of $20 \mathrm{~min}$ followed by $0.25 \% \mathrm{HgCl}_{2}$ has resulted in $80 \%$ contamination-free and $70 \%$ live explants after three weeks of incubation. Likewise, cefotaxime at 50,100, and $200 \mathrm{mg} / \mathrm{L}$ and cefotaxime plus streptomycin at 25,50 , and $100 \mathrm{mg} / \mathrm{L}$ yielded 87 to $93 \%$ contamination-free microshoots after three weeks of culturing. The number of explants killed by the antibiotics increased with increasing the concentration of the antibiotics. Cefotaxime at $50 \mathrm{mg} / \mathrm{L}$ and cefotaxime plus streptomycin at $25 \mathrm{mg} / \mathrm{L}$ yielded significantly highest mean microshoots per explant $(7.10 \pm 0.36$ and $7.51 \pm 0.27$, respectively) and mean shoot length $(4.2 \pm 0.26$ and $3.56 \pm 0.17 \mathrm{~cm}$, respectively). Some of the microshoots showed some yellowing. But, they turned green and grew normal after subcultured into fresh, antibiotics-free culture media. These findings are important foundations towards developing more optimized protocols of sterilizing explants and controlling bacterial contaminants for large-scale in vitro micropropagation of the Deribo ginger cultivar.

\section{Introduction}

Ginger (Zingiber officinale Rosc) (Zingiberaceae) is one of the world's most important medicinal and culinary spice plant [1]. It is a perennial herbaceous plant but cultivated as an annual crop. The plant has an erect stem covered with leaf sheaths, $15-20 \mathrm{~cm}$ long and $2-3 \mathrm{~cm}$ wide alternate leaves, a laterally compressed and palmately branched underground stem called rhizome, and fine fibrous roots [2]. Both fresh and dried rhizomes of ginger are valuable all over the world as spice and herbal medicine [3-5]. The plant is, thus, commercially cultivated in several countries including China, Fiji, India, Indonesia, Jamaica, Japan, Mexico, Philippines, and Taiwan, as well as in many African countries [6]. The crop thrives best in warm and humid climates from the sea level to 1,600 meters, with a mean temperature between 20 and $32^{\circ} \mathrm{C}$ and total annual rainfall of 1500 to $3000 \mathrm{~mm}$ [7]. It performs well in well-drained, fertile, and friable soil with a neutral $\mathrm{pH}[8]$. 
Multiple varieties of ginger are extensively cultivated in southern and western Ethiopia. The plant is the principal livelihood crop in southern Ethiopia [9] covering about 85\% of the arable land of the Southern Nations, Nationalities, and Peoples' State of Ethiopia [10]. It is a principal cash crop for small-scale farmers and one of the important commodities for local small-scale traders and wholesellers. Ginger is the most common spice in almost all Ethiopian traditional dishes. It is also used in the preparation of hot drinks and remedies. Currently, it is one of the most valued export commodities for Ethiopia [9, 11].

Being one of the 45 Ethiopian ginger cultivars, Deribo is fibrous and more pungent with higher content of volatile oil compared to the Asian ginger variety. Its taste is similar to a Nigerian ginger variety and is well-accepted in western cuisine. Ginger has been Ethiopia's number one export spice till 2013 [12]. It is given special focus in the Ethiopian agricultural transformation and export trade plan. Unfortunately, bacterial wilt is becoming a serious threat to ginger production and productivity in the country. The disease started spreading throughout Ethiopia since 2014, and producers have reported up to $98 \%$ yield loss in $2014[11,12]$. The causative agent of the wilt is Ralstonia solanacearum Biovar 3 Race 4 . It is already distributed throughout all ginger growing areas by recycling of seed rhizomes as the growers were neither aware about it nor have the knowledge to control its spread [11].

This national crisis requires the development of some strategy. The pathogen is soil-borne bacteria. Thus, not only the rhizomes are infected but also the ginger-growing soils are contaminated with the pathogen. The rhizomes often accumulate high dose of the pathogen and become unsuitable as planting materials. This calls for some dependable strategy aiming at producing vigorous, disease-free planting materials. In fact, there has been a growing demand for clean and healthy planting materials of improved and adapted varieties [13]. Large-scale in vitro micropropagation of the crop becomes the only viable strategy for mitigating the problem quickly and extensively. Tigrai Biotechnology Center Pvt. Ltd. Co., located in Mekelle (Ethiopia), is the only facility capable of producing millions of disease-free plantlets in few years. It can produce up to 40 million plantlets per annum. Currently, the facility is carrying out large-scale in vitro micropropagation of three cultivars of ginger, namely, Boziab, Deribo, and Yali.

However, the success of large-scale in vitro micropropagation principally depends on developing a good protocol, including the development of effective protocol of explant and media sterilization. Growth media and plantlets contamination is the main cause of loss in large-scale micropropagation facilities. While bacterial contamination of media can be controlled by autoclaving, the contamination of plantlets is very difficult to control, especially if the contaminants are endophytic such as the causative agent of ginger wilt disease [14]. Explants derived from Ethiopian ginger cultivars are highly unlikely to be free of the $R$. solanacearum Biovar 3 Race 4 bacteria. Moreover, surface sterilization can only clean the bacteria off the explants. Thus, the formulation of the growth media has to be enriched with chemical agents or antibiotics that kill the pathogenic bacteria. The use of broad-spectrum antibiotics such as streptomycin, kanamycin, cefotaxime, and gentamicin to enrich in vitro micropropagation media is a preferred procedure [15-17].

Clonal propagation of ginger is a well-established technology throughout the world. Shoot tips, axillary buds, root tips, rhizome axillary buds, vegetative buds, sprouting buds, young buds, and rhizome buds have been used as explants for in vitro regeneration of many ginger varieties successfully $[3,5,6,13,18-21]$. Likewise, clonal propagation of many Ethiopian ginger cultivars was attempted successfully using rhizome buds, shoot tips, and others sources of explants [10, 13]. However, explants derived from rhizome buds and similar structures produce limited number of offshoots per year. Clonal propagation using rhizome buds and other vegetative structures is not helpful in producing millions of planting materials quickly [19]. Shoot tips and shootlets or microshoots derived from rhizome buds are good choices as explants for rapid, large-scale in vitro micropropagation of the plant to alleviate this problem $[6,13,19]$. However, ginger shoot tips are not free of the pathogenic bacteria discussed above and many other contaminants. In fact, the technicians at the Tigrai Biotechnology Center have observed that in vitro cultures of Deribo cultivar are especially vulnerable to bacterial contamination. Therefore, this article reports the results of a study that attempted to develop a protocol of controlling bacterial contamination using three disinfectants and four broadspectrum antibiotics for the in vitro micropropagation of the Ethiopian ginger cultivar of Deribo through shoot tip explants.

\section{Materials and Methods}

The experiment was conducted at the Tigrai Biotechnology Center Pvt. Ltd. Co. Lab, formerly known as Mekelle Plant Tissue Culture Laboratory. The center is located in Mekelle, Tigrai, Ethiopia (alt.: 1979 masl; lat.: $13^{\circ} 30^{\prime \prime} 0^{\prime} \mathrm{N}$; long.: $39^{\circ} 28^{\prime \prime} 11^{\prime} \mathrm{E}$ ) about $200 \mathrm{~km}$ southeast of the historic city of Aksum. It has the capacity of producing more than 40 million plantlets per annum.

2.1. Collection of Mother Plants and Explants. Mother plants (i.e., rhizomes) of the Deribo ginger cultivar ( $Z$. officinale Rosc) used in this study were collected from the Hadiya and Kembata areas of the Southern Nations, Nationalities, and Peoples' State of Ethiopia. Vigorous rhizomes were selected and were sprayed with a mixture of ridomile, bayleton, and kocide. Then, they were put in moist coco peat to sprout and maintained in greenhouse for several weeks. Then, 90 shoot tips (2-3 cm long) were collected by excising from sprouted rhizomes as explants for in vitro micropropagation.

2.2. Preparation and Sterilization of Explants. Shoot tip explants were washed thoroughly with tap water and soap solution to remove traces of any dirt particles. Then, they were washed with sterile distilled water until all traces of the 
soap solution were removed and were readied for treatment. The study was designed to test the effectiveness of three surface sterilization agents, namely, $0.25 \% \mathrm{v} / \mathrm{w}$ RBK (labmade antimicrobial agent composed of ridomile, bayleton, and kocide at a ratio of $1: 1: 1$ ) (3 treatments), $70 \% \mathrm{v} / \mathrm{v}$ ethanol (3 treatments), and $0.50 \% \mathrm{v} / \mathrm{v} \mathrm{NaOCl}$ (sodium hypochlorite) (3 treatment) in combination with of $0.25 \%$ $\mathrm{HgCl}_{2}$ (mercuric chloride). Surface sterilization using $0.25 \%$ RBK involved the treatment of the explants with the agent for 30,45 , and 60 minutes. Sterilization procedure using $0.50 \% \mathrm{NaOCl}$ involved the treatment of explants for 10,20 , and $30 \mathrm{~min}$. Sterilization using $70 \%$ ethanol involved treatment of the explants for 5, 10, and $15 \mathrm{~min}$. In all cases, the explants were surface sterilized with $0.25 \% \mathrm{HgCl}_{2}$ for 10 more min under the laminar airflow cabinet. Finally, the explants were washed with double distilled water to remove any traces of the $\mathrm{HgCl}_{2}$ and were readied for inoculation.

2.3. Preparation of In Vitro Culture Media. The study used Murashige and Skoog [22] (MS) media for in vitro culturing of the explants. Full-strength MS media were prepared by adding required stock solutions of micronutrients, macronutrients, and additives and by enriching with $30 \mathrm{~g}$ of sucrose (C-source) and $5 \mathrm{~g}$ of agar as solidifying agent. The $\mathrm{pH}$ of the solutions was adjusted to about 5.8 by adding drops of $0.1 \mathrm{~N} \mathrm{HCl}$ and $0.1 \mathrm{~N} \mathrm{NaOH}$ as appropriate. The content was heated at $90^{\circ} \mathrm{C}$. Required number of initiation and shooting media were prepared by readying $40 \mathrm{~mL}$ culture media in $300 \mathrm{~mL}$ magenta culture bottles. Whilethe MS media assigned for initiation were enriched with $2.0 \mathrm{mg} / \mathrm{L}$ (BAP), those assigned for shooting were enriched with $4.0 \mathrm{mg} / \mathrm{L}$ BAP. All treatments were prepared in three replications. Finally, the media were autoclaved at $121^{\circ} \mathrm{C}$ and 15 psi for $20 \mathrm{~min}$. While the initiation media were allowed to cool at room temperature to $60^{\circ} \mathrm{C}$, the shooting media were enriched with antibiotics while cooling. The required concentrations and combinations of antibiotics were added to shooting media while they were cooling but not solidified. Finally, they were kept for a week to inspect their sterility and fitness for use. Some media were left without antibiotics to serve as control. Four broad-spectrum antibiotics, namely streptomycin, kanamycin, gentamicin, and cefotaxime were used alone at the rate of 50,100 , and $200 \mathrm{mg} / \mathrm{L}$, as well as in possible combinations of two antibiotics at 25, 50, and $100 \mathrm{mg} / \mathrm{L}$ [15].

2.4. Inoculation and Incubation of Explants. The initiation and shooting media were inoculated with tip shoot explants at the rate of one shoot per bottle under a laminar airflow cabinet. Culture bottles of the treatments were placed on growth racks in a completely randomized design. The growth room was adjusted to $25 \pm 2^{\circ} \mathrm{C}$ under a fluorescent tube light with 16/8 hours light/dark photoperiod and a light intensity of 1,200 lux. The shoot tip explants were incubated for three weeks. The explants were subcultured into fresh media twice in the interval of three weeks to produce enough microshoots for the shooting experiment. The inoculation and incubation of the shooting media were carried out with the same procedure except five microshoots which were put into each culture bottle holding shooting media.

2.5. Data Sources and Analyses. Quantitative data were the explant survival rate and rate of contamination of explants in initiation and shooting media, number of shoots per explant, and shoot length. Qualitative data included color and gross morphology of shoots. The data were collected after three weeks of incubation for initiation and shooting. Treatment effects in all tests were determined by using the analysis of variance (ANOVA) using the statistical package for social science (SPSS version 20) and means were compared using the Least Significant Difference (LSD). All comparisons were made at a priori significance level of $p \leq 0.05$.

\section{Results and Discussion}

3.1. The Effects of Surface Sterilizers for Ginger Shoot Explants. The purpose of this study was to develop a standard procedure of surface sterilization of explants of the Deribo Ethiopian ginger cultivar and its in vitro micropropagation media. For this purpose, the effects of three sterilization agents with three exposure (treatment) times were tested. Sodium hypochlorite $(0.50 \% \mathrm{v} / \mathrm{v})$ at $20 \mathrm{~min}$ treatment time yielded a significantly highest mean number $(8.00 \pm 1.73)$ of clean explants after three weeks of incubation (Table 1; $p \leq 0.05)$. The treatment yielded $80 \%$ clean explants. $\mathrm{NaOCl}$ at 20 and $30 \mathrm{~min}$ treatment and $70 \%$ ethanol at 5 and $10 \mathrm{~min}$ treatment produced the highest mean numbers of live explants $(7.33 \pm 0.58$ to $7.00 \pm 1.00)$. But, the $70 \%$ ethanol (at all treatment times) was less effective in its disinfecting capacity.

Water (tap, distilled, and sterile), detergent solutions, antibacterial and antifungal agents, $\mathrm{NaOCl}, \mathrm{CaOCl}_{2}$, ethanol, $\mathrm{HgCl}_{2}$, and antibiotics are the usual agents of sterilization of explants and controlling in vitro growth media contamination. The RBK detergent, $\mathrm{NaOCl}$, ethanol, and $\mathrm{HgCl}_{2}$ are the most commonly used surface sterilization agents in preparing sterile explants for in vitro multiplication of many species and plant materials [23-28]. While the RBK, $\mathrm{NaOCl}$, and ethanol are used as primary sterilization agents, the $\mathrm{HgCl}_{2}$ is often used as the secondary sterilization agent following the primary agents. In fact, some studies also showed that the $\mathrm{HgCl}_{2}$ can be effective when used alone $[6,29,30]$. But, their effectiveness might not show clear patterns. While Khatun et al. [29] observed $0.10 \% \mathrm{HgCl}_{2}$ at 10 min exposure time to be the most effective, Suma et al. [30] observed the best sterilization result with the same concentration but shorter time in treating rhizome buds of ginger.

We looked into the effectiveness of the three primary sterilization agents in combination with $\mathrm{HgCl}_{2}$. The use of all these agents through some suitable procedures is more effective for sterilization than used singly [23-25]. But, simple disinfection or sterilization procedures save time and resources and cause less damage to the explants and, thus, are 
TABLE 1: Effect of surface disinfectants on contamination and survival of shoot tip explants of ginger (Z. officinale Rosc).

\begin{tabular}{llllll}
\hline Treatment & Time (in & $\begin{array}{c}\text { No. of clean } \\
\text { explants }\end{array}$ & $\begin{array}{c}\text { No. of survived } \\
\text { explants }\end{array}$ \\
Disinfectant & $\begin{array}{l}\text { Mean (SD) } \\
\text { min) }\end{array}$ & $\%$ & Mean (SD) & $\%$ \\
\hline \multirow{2}{*}{$\mathrm{RBK}(0.25 \% \mathrm{w} /$} & 30 & $4.33(0.58)^{\mathrm{c}}$ & 43 & $5.68(0.58)^{\mathrm{b}}$ & 57 \\
$\mathrm{v})$ & 45 & $4.00(1.00)^{\mathrm{c}}$ & 40 & $4.68(0.58)^{\mathrm{bc}}$ & 47 \\
& 60 & $3.33(0.58)^{\mathrm{c}}$ & 33 & $5.68(0.58)^{\mathrm{b}}$ & 57 \\
\hline \multirow{2}{*}{$\mathrm{NaOCl}(0.50 \%$} & 10 & $3.67(0.58)^{\mathrm{c}}$ & 37 & $3.68(0.58)^{\mathrm{c}}$ & 37 \\
$\mathrm{v} / \mathrm{v})$ & 20 & $8.00(1.73)^{\mathrm{a}}$ & 80 & $7.33(0.58)^{\mathrm{a}}$ & 73 \\
& 30 & $6.33(0.58)^{\mathrm{b}}$ & 63 & $7.00(1.00)^{\mathrm{a}}$ & 70 \\
\hline \multirow{2}{*}{ Ethanol (70\% v/ $/ 2$} & $4.66(0.58)^{\mathrm{c}}$ & 47 & $7.33(0.58)^{\mathrm{a}}$ & 73 \\
v) & 10 & $3.66(0.58)^{\mathrm{c}}$ & 37 & $7.00(1.00)^{\mathrm{a}}$ & 70 \\
& 15 & $4.33(1.15)$ & 43 & $6.33(0.58)^{\mathrm{ab}}$ & 63 \\
\hline
\end{tabular}

Means in the same column with different letters are statistically significantly different at $p \leq 0.05$; $\mathrm{SD}$ : standard deviation.

most preferred. This study showed that $\mathrm{NaOCl}(0.50 \% \mathrm{v} / \mathrm{v})$ at 20 min treatment time in combination with $\mathrm{HgCl}_{2}$ at $10 \mathrm{~min}$ of treatment time yielded the best sterilization result. Similar results were reported with 20 min treatment time elsewhere [31]. Other researchers reported good sterilization results with lower concentration and exposure time of $\mathrm{NaOCl}$ $[5,29]$. However, other workers showed that $\mathrm{NaOCl}$ at 10 min treatment time is less effective [6]. Such differences may be attributable to the genotypes of the plants or the types of explants. Anyway, care has to be taken that higher concentration of $\mathrm{NaOCl}(0.50 \% \mathrm{v} / \mathrm{v})$, and other agents might cause some damage to the tissues of the explants to cause more contamination and death of explants $[29,32,33]$.

The effectiveness of $70 \%$ ethanol somehow decreases with exposure (treatment) time where the number of clean and live explants decrease with increasing exposure time. This decreasing effectiveness is believed to be linked to damages of tissues due to the phytotoxicity of the alcohol [32]. But, other researchers reported about the effectiveness of $70 \%$ ethanol $(15 \mathrm{sec})$ in combination with $\mathrm{HgCl}_{2}$ in sterilizing ginger explants for micropropagation $[13,20]$. The use of fungicide and bactericide detergents like RBK in combination with other agents is a common practice for effective preliminary (or surface) sterilization of explants for in vitro propagation of many species [23-25]. However, the present study showed that RBK $(0.25 \% \mathrm{w} / \mathrm{v})$ was not effective at 30,45 , or $60 \mathrm{~min}$ exposure time. In fact, increasing exposure time caused more contaminated explants. Similar observations were reported with Bavistin and Carbendazim disinfectants by other researchers [32, 34]. Yet, other researchers reported good sterilizing capacity of Bavistin in cleaning ginger explants for tissue culture $[35,36]$.

3.2. The Efficacy of Antibiotics in Controlling Bacterial Contamination. Microbial contamination is another critical problem in plant in vitro clonal propagation [37]. It causes big loss to tissue culture and micropropagation companies by affecting the efficiency of propagation and the quality of the outputs [38-40]. This is because customary cultural and management practices are not always sufficient to control microbial contamination of tissue culture facilities and in vitro cultures [17]. Thus, the use of antibiotics is highly recommended to alleviate the problem [41]. The sources of contamination of in vitro cultures are diverse. Among other things, explants collected from field-grown plants acquire the contaminants from soil $[42,43]$ or water [44]. It becomes customary to devise procedures to clean the explants off microbial contaminants. The growth media may also be treated with antibiotics to control the growth of bacteria and fungi when the problem of contamination cannot be mitigated by other procedures [45].

The present study tested the effectiveness of four broad-spectrum antibiotics in controlling bacterial contamination of in vitro growth media of shoot tip explants of the Deribo cultivar. First, the efficacies of the antibiotics streptomycin, kanamycin, gentamicin, and cefotaxime were tested singly or in combination of two at three different concentrations. The efficacies of each of the antibiotics were tested at the 50, 100, and $200 \mathrm{mg} / \mathrm{L}$ concentrations. Streptomycin, kanamycin, and gentamicin were ineffective at all concentrations yielding 0 to $27 \%$ clean microshoots. However, cefotaxime was found to be effective at all concentrations yielding significantly higher mean number of clean microshoots $(4.33 \pm 1.15$ to $4.67 \pm 0.58$ or 87 to $93 \%$ ) (Table $2 ; p \leq 0.05$ ). Unfortunately, except at $50 \mathrm{mg} / \mathrm{L}$, the other concentrations caused the death of 40 to $47 \%$ of the microshoots.

The use of single antibiotics may not be effective in controlling bacterial contamination of the explants or the media. Thus, the use of a combination of antibiotics is advisable. The present study also examined the efficacies of the possible combinations of two of the four antibiotics in controlling bacterial contamination. Of all the treatments, the combination of cefotaxime and streptomycin at 25 to $100 \mathrm{mg} /$ $\mathrm{L}$ yielded higher mean number of clean microshoots $(4.33 \pm 1.15$ to $4.67 \pm 0.57$ or 87 to $93 \%$ ) (Table $3 ; p \leq 0.05$ ). Interestingly, three pairs of antibiotics, namely, streptomycin and kanamycin, kanamycin and cefotaxime, and kanamycin and gentamicin failed to produce any clean microshoots.

Antibiotics are often used in controlling bacterial and fungal contamination of in vitro explants and growth media. Unfortunately, the antibiotics could damage essential tissues of explants or kill the explants altogether. Hence, identification of the best antibiotics (or combination of antibiotics), the establishment of the optimum concentration, and the determination of the best exposure time become necessary. Our study showed that only $50 \mathrm{mg} / \mathrm{L}$ cefotaxime was effective in producing $87 \%$ clean and live explants while higher concentrations were phytotoxic. Likewise, the application of cefotaxime in combination with streptomycin (at $25 \mathrm{mg} / \mathrm{L}$ ) yielded $87 \%$ clean explants. Similar findings were reported with cefotaxime alone and in combination with streptomycin sulphate in controlling bacterial contamination in ginger shoot explant at 50 to $200 \mathrm{mg} / \mathrm{L}$ [15]. The application of cefotaxime singly or in combination with other antibiotics was also reported to be effective in controlling bacterial contamination in explants and culture media [41]. 
TABLE 2: The effects of antibiotics on the in vitro bacterial contamination of microshoots of ginger ( $Z$. officinale Rosc).

\begin{tabular}{lccccc}
\hline Treatment & mg/L & $\begin{array}{c}\text { No. of clean } \\
\text { plantlets } \\
\text { Mean (SD) }\end{array}$ & $\begin{array}{c}\text { No. of killed } \\
\text { explants }\end{array}$ \\
\hline Control & 0 & $0.00(0.00)^{\mathrm{c}}$ & 0 & $4.00(0.00)^{\mathrm{a}}$ & 80 \\
\hline \multirow{3}{*}{ Streptomycin } & 50 & $0.00(0.00)^{\mathrm{c}}$ & 0 & $1.00(0.00)^{\mathrm{c}}$ & 20 \\
& 100 & $0.33(0.57)^{\mathrm{bc}}$ & 7 & $2.00(1.00)^{\mathrm{b}}$ & 40 \\
& 200 & $1.33(1.52)^{\mathrm{b}}$ & 27 & $2.67(1.15)^{\mathrm{a}}$ & 53 \\
\hline \multirow{5}{*}{ Kanamycin } & 50 & $0.00(0.00)^{\mathrm{c}}$ & 0 & $0.33(0.57)^{\mathrm{c}}$ & 7 \\
& 100 & $0.33(0.57)^{\mathrm{bc}}$ & 7 & $1.00(0.00)^{\mathrm{bc}}$ & 20 \\
& 200 & $0.67(0.57)^{\mathrm{bc}}$ & 13 & $3.33(1.52)^{\mathrm{a}}$ & 67 \\
\hline \multirow{5}{*}{ Gentamicin } & 50 & $0.00(0.00)^{\mathrm{c}}$ & 0 & $1.67(0.57)^{\mathrm{bc}}$ & 33 \\
& 100 & $1.00(0.00)^{\mathrm{bc}}$ & 13 & $2.00(1.00)^{\mathrm{b}}$ & 40 \\
& 200 & $1.33(0.57)^{\mathrm{b}}$ & 27 & $3.00(1.00)^{\mathrm{a}}$ & 60 \\
\hline \multirow{3}{*}{ Cefotaxime } & 50 & $4.33(1.15)^{\mathrm{a}}$ & 87 & $0.00(0.00)^{\mathrm{c}}$ & 0 \\
& 100 & $4.33(0.57)^{\mathrm{a}}$ & 87 & $2.00(1.00)^{\mathrm{b}}$ & 40 \\
& 200 & $4.67(0.57)^{\mathrm{a}}$ & 93 & $2.33(0.57)^{\mathrm{b}}$ & 47 \\
\hline
\end{tabular}

Means in the same column with different letters are statistically significantly different at $p \leq 0.05$; SD: standard deviation.

Streptomycin plus gentamicin, as well as cefotaxime and gentamicin, yielded some clean explants. It is useful to note that cefotaxime did not produce clean explants when combined with kanamycin. The antibiotic combinations that did not produce clean microshoots caused the death of many microshoots. Streptomycin in combination with cefotaxime at $25 \mathrm{mg} / \mathrm{L}$ caused the lowest death of explants (Table 3). Other studies showed best results with gentamicin [46, 47] and streptomycin sulphate $[15,34,48]$. Gentamicin and streptomycin alone or in combination with each other and with the other antibiotics were ineffective. Limited efficacy of streptomycin even at higher dose was also reported elsewhere [41]. Contrarily, Mengs [37] reported 75\% clean explants of ginger with $100 \mathrm{mg} / \mathrm{L}$ of streptomycin but with $47 \%$ survival rate.

3.3. Effects of the Antibiotics on Shooting Performance of Ginger Explants. The principal goal of in vitro regeneration of plants is to produce mass of healthy and vigorous plantlets quickly. Therefore, any treatment of tissue culture media and/ or the plantlets aiming at controlling microbial contaminants should not interfere with the plant growth regulators, the MS media, and the structure and function of the plantlets (i.e., the quality of the plantlets). Chemical agents and antibiotics that adversely affect in vitro regeneration are useless. The present study looked into the effects of the four antibiotics (alone and in combination) on the shooting performances of shoot tip explants of the Deribo ginger cultivar.

The study on the effects each antibiotics showed that the highest mean shoot number per explant was observed with $50 \mathrm{mg} / \mathrm{L}$ cefotaxime $(7.10 \pm 0.36 ; p \leq 0.05)$. The next highest mean shoot number $(2.86 \pm 0.59)$ was observed with the same antibiotics at $100 \mathrm{mg} / \mathrm{L}$ (Table 4 ). All other treatments yielded a mean shoot number of 1.00 (in control) to $2.46 \pm 0.16$ (with $200 \mathrm{mg} / \mathrm{L}$ cefotaxime). Likewise, cefotaxime yielded better mean shoot length ranging from $2.02 \pm 0.23 \mathrm{~cm}$ (with $200 \mathrm{mg}$ / L) to $4.20 \pm 0.26 \mathrm{~cm}$ (with $50 \mathrm{mg} / \mathrm{L}$ ). With the exception of
TABLE 3: Effects of antibiotic combinations on the in vitro bacterial contamination of ginger ( $Z$. officinale Rosc).

\begin{tabular}{|c|c|c|c|c|c|}
\hline \multirow{2}{*}{ Treatment } & \multirow{2}{*}{$\begin{array}{c}\mathrm{mg} / \\
\mathrm{L}\end{array}$} & \multicolumn{2}{|c|}{$\begin{array}{c}\text { No. of clean } \\
\text { plantlets }\end{array}$} & \multicolumn{2}{|c|}{$\begin{array}{c}\text { No. of killed } \\
\text { explants }\end{array}$} \\
\hline & & Mean (SD) & $\%$ & $\begin{array}{c}\text { Mean } \\
(\mathrm{SD})\end{array}$ & $\%$ \\
\hline Control & & $0.00(0.00)^{\mathrm{f}}$ & 0 & $\begin{array}{c}4.00 \\
(0.00)^{\mathrm{ab}}\end{array}$ & 80 \\
\hline \multirow{3}{*}{ Streptomycin + kanamycin } & 25 & $0.00(0.00)^{\mathrm{f}}$ & 0 & $\begin{array}{c}1.33 \\
(1.15)^{\mathrm{cd}}\end{array}$ & 27 \\
\hline & 50 & $0.00(0.00)^{\mathrm{f}}$ & 0 & $\begin{array}{c}4.00 \\
(1.00)^{\mathrm{ab}}\end{array}$ & 80 \\
\hline & 100 & $0.00(0.00)^{\mathrm{f}}$ & 0 & $\begin{array}{c}3.67 \\
(1.50)^{\mathrm{ab}}\end{array}$ & 73 \\
\hline \multirow{3}{*}{ Streptomycin + gentamicin } & 25 & $0.67(0.57)^{\mathrm{ef}}$ & 13 & $\begin{array}{c}1.00 \\
(1.00)^{\mathrm{cd}}\end{array}$ & 20 \\
\hline & 50 & $1.33(0.57)^{\mathrm{e}}$ & 20 & $\begin{array}{c}1.33 \\
(0.57)^{\mathrm{cd}}\end{array}$ & 27 \\
\hline & 100 & $1.67(1.15)^{\mathrm{de}}$ & 33 & $\begin{array}{c}2.67 \\
(1.52)^{\mathrm{bc}}\end{array}$ & 53 \\
\hline \multirow{3}{*}{ Streptomycin + cefotaxime } & 25 & $4.33(1.15)^{\mathrm{b}}$ & 87 & $\begin{array}{c}0.67 \\
(0.57)^{\mathrm{cd}}\end{array}$ & 13 \\
\hline & 50 & $4.33(0.57)^{\mathrm{b}}$ & 87 & $\begin{array}{c}1.33 \\
(1.15)^{\mathrm{cd}}\end{array}$ & 27 \\
\hline & 100 & $4.67(0.57)^{\mathrm{a}}$ & 93 & $\begin{array}{c}1.67 \\
(1.15)^{\mathrm{cd}}\end{array}$ & 33 \\
\hline \multirow{3}{*}{ Kanamycin + cefotaxime } & 25 & $0.00(0.00)^{\mathrm{f}}$ & 0 & $\begin{array}{c}4.67 \\
(0.57)^{\mathrm{a}}\end{array}$ & 93 \\
\hline & 50 & $0.00(0.00)^{\mathrm{f}}$ & 0 & $\begin{array}{c}2.67 \\
(1.15)^{b c}\end{array}$ & 53 \\
\hline & 100 & $0.00(0.00)^{\mathrm{f}}$ & 0 & $\begin{array}{c}3.33 \\
(1.52)^{\mathrm{ab}}\end{array}$ & 67 \\
\hline \multirow{3}{*}{ Kanamycin + gentamicin } & 25 & $0.00(0.00)^{\mathrm{f}}$ & 0 & $\begin{array}{c}3.00 \\
(1.00)^{\mathrm{bc}}\end{array}$ & 60 \\
\hline & 50 & $0.00(0.00)^{\mathrm{f}}$ & 0 & $\begin{array}{c}3.33 \\
(0.57)^{\mathrm{ab}}\end{array}$ & 67 \\
\hline & 100 & $0.00(0.00)^{\mathrm{f}}$ & 0 & $\begin{array}{c}3.67 \\
(0.57)^{\mathrm{ab}} \\
\end{array}$ & 73 \\
\hline \multirow{3}{*}{ Cefotaxime + gentamicin } & 25 & $2.00(1.00)^{\mathrm{de}}$ & 40 & $\begin{array}{c}2.00 \\
(1.00)^{\mathrm{cd}}\end{array}$ & 40 \\
\hline & 50 & $\begin{array}{c}2.33 \\
(0.57)^{\mathrm{cd}}\end{array}$ & 47 & $\begin{array}{c}1.67 \\
(1.15)^{\mathrm{cd}}\end{array}$ & 33 \\
\hline & 100 & $3.00(1.00)^{\mathrm{c}}$ & 60 & $\begin{array}{c}2.67 \\
(0.57)^{\mathrm{bc}}\end{array}$ & 53 \\
\hline
\end{tabular}

Means in the same column with different letters are statistically significantly different at $p \leq 0.05$; $\mathrm{SD}$ : standard deviation.

streptomycin yielding a mean shoot length of $2.50+0.25 \mathrm{~cm}$, the rest of the treatments produced a mean shoot length of 0.50 to $1.68 \mathrm{~cm}$. However, some of the microshoots produced in the cefotaxime-treated media were getting yellowish. The more the concentration of the antibiotics gets, the more the plantlets become yellowish.

Likewise, the test on the effects of combinations of the antibiotics showed that cefotaxime in combination with streptomycin (at $25 \mathrm{mg} / \mathrm{L}$ ) produced the highest mean shoot number $(7.51 \pm 0.27)$ per explant. The second highest mean shoot numbers were recorded in shooting media treated with cefotaxime plus gentamicin $(3.10 \pm 0.17)$ and cefotaxime plus streptomycin $(3.01 \pm 0.27)$ (Table 5). By the same token, 
TABLE 4: Effects of single antibiotics on shooting performance of ginger (Z. officinale Rosc).

\begin{tabular}{lcccc}
\hline Treatment & $\mathrm{mg} / \mathrm{L}$ & Mean $(\mathrm{SD})$ shoot number & Mean shoot length $(\mathrm{cm})$ & (\%) Color change \\
\hline Control & 0 & $1.00(0.00)^{\mathrm{e}}$ & $0.50(0.00)^{\mathrm{e}}$ & 0 \\
\hline \multirow{3}{*}{ Streptomycin } & 50 & $2.25(0.25)^{\mathrm{cd}}$ & $2.50(0.25)^{\mathrm{b}}$ & $1.68(0.06)^{\mathrm{cd}}$ \\
& 100 & $2.19(0.17)^{\mathrm{cd}}$ & $0.55(0.09)^{\mathrm{e}}$ & 0 \\
& 200 & $1.11(0.19)^{\mathrm{e}}$ & $0.92(0.06)^{\mathrm{e}}$ & 0 \\
Kanamycin & 50 & $1.63(0.15)^{\mathrm{d}}$ & $0.75(0.13)^{\mathrm{e}}$ & $0.51(0.02)^{\mathrm{e}}$ \\
& 100 & $1.50(0.25)^{\mathrm{d}}$ & $1.40(0.08)^{\mathrm{d}}$ & 0 \\
\hline \multirow{3}{*}{ Gentamicin } & 200 & $1.08(0.14)^{\mathrm{e}}$ & $1.00(0.33)^{\mathrm{de}}$ & 0 \\
& 50 & $1.94(0.48)^{\mathrm{d}}$ & $1.20(0.32)^{\mathrm{de}}$ & 0 \\
\hline \multirow{3}{*}{ Cefotaxime } & 100 & $1.89(0.19)^{\mathrm{d}}$ & $4.20(0.26)^{\mathrm{a}}$ & 13 \\
& 200 & $1.72(0.25)^{\mathrm{d}}$ & $2.86(0.55)^{\mathrm{b}}$ & 29 \\
\hline
\end{tabular}

Means in the same column with different letters are statistically significantly different at $p \leq 0.05$; SD: standard deviation.

TABLE 5: Effects of antibiotic combinations on the shooting performance of ginger (Z. officinale Rosc).

\begin{tabular}{|c|c|c|c|}
\hline Treatment & $\mathrm{mg} / \mathrm{L}$ & $\begin{array}{c}\text { No. of shoots/explant } \\
\text { Mean (SD) }\end{array}$ & $\begin{array}{c}\text { Length of shoots }(\mathrm{cm}) \\
\text { Mean }(\mathrm{SD})\end{array}$ \\
\hline Control & & $1.00(0.00)^{\mathrm{e}}$ & $0.50(0.00)^{\mathrm{e}}$ \\
\hline Streptomycin + kanamycin & $\begin{array}{c}25 \\
50 \\
100 \\
\end{array}$ & $\begin{array}{l}1.60(0.24)^{\mathrm{d}} \\
0.67(0.57)^{\mathrm{ef}} \\
0.67(0.57)^{\mathrm{ef}}\end{array}$ & $\begin{array}{c}0.69(0.20)^{\mathrm{de}} \\
0.40(0.36)^{\mathrm{e}} \\
0.46(0.39)^{\mathrm{e}}\end{array}$ \\
\hline Streptomycin + gentamicin & $\begin{array}{c}25 \\
50 \\
100 \\
\end{array}$ & $\begin{array}{l}1.37(0.32)^{\mathrm{de}} \\
1.75(0.25)^{\mathrm{d}} \\
1.41(0.38)^{\mathrm{de}}\end{array}$ & $\begin{array}{c}0.71(0.20)^{\mathrm{de}} \\
0.87(0.12)^{\mathrm{d}} \\
0.91(0.14)^{\mathrm{d}}\end{array}$ \\
\hline Streptomycin + cefotaxime & $\begin{array}{c}25 \\
50 \\
100\end{array}$ & $\begin{array}{l}7.51(0.27)^{\mathrm{a}} \\
3.01(0.27)^{\mathrm{b}} \\
2.41(0.14)^{\mathrm{c}}\end{array}$ & $\begin{array}{c}3.56(0.17)^{\mathrm{a}} \\
1.97(0.05)^{\mathrm{bc}} \\
1.62(0.21)^{\mathrm{c}}\end{array}$ \\
\hline Kanamycin + cefotaxime & $\begin{array}{c}25 \\
50 \\
100 \\
\end{array}$ & $\begin{array}{l}0.33(0.57)^{\mathrm{f}} \\
1.56(0.19)^{\mathrm{d}} \\
1.49(0.18)^{\mathrm{de}}\end{array}$ & $\begin{array}{l}0.16(0.28)^{\mathrm{e}} \\
0.93(0.20)^{\mathrm{d}} \\
0.82(0.16)^{\mathrm{de}}\end{array}$ \\
\hline Kanamycin + gentamicin & $\begin{array}{c}25 \\
50 \\
100 \\
\end{array}$ & $\begin{array}{l}1.00(0.00)^{\mathrm{e}} \\
1.17(0.28)^{\mathrm{de}} \\
1.33(0.57)^{\mathrm{de}}\end{array}$ & $\begin{array}{l}0.60(0.10)^{\mathrm{de}} \\
0.58(0.14)^{\mathrm{de}} \\
0.63(0.11)^{\mathrm{de}}\end{array}$ \\
\hline Cefotaxime + gentamicin & $\begin{array}{c}25 \\
50 \\
100\end{array}$ & $\begin{array}{l}3.10(0.17)^{\mathrm{b}} \\
1.91(0.14)^{\mathrm{cd}} \\
2.50(0.17)^{\mathrm{bc}}\end{array}$ & $\begin{array}{l}2.27(0.25)^{\mathrm{bc}} \\
1.92(0.14)^{\mathrm{bc}} \\
1.78(0.38)^{\mathrm{c}}\end{array}$ \\
\hline
\end{tabular}

Means in the same column with different letters are statistically significantly different at $p \leq 0.05$; SD: standard deviation.

statistically highest mean shoot length values were recorded in treatments with cefotaxime plus streptomycin $(3.56 \pm 0.17 \mathrm{~cm})$ and cefotaxime plus gentamicin $(2.27 \pm 0.25 \mathrm{~cm})$. The cefotaxime plus streptomycin caused the yellowing of 7 to $36 \%$ of plantlets. Interestingly, when the plantlets were subcultured into fresh, antibiotics-free media, they grew normal and turned green. Similar observation was reported elsewhere [41].

We observed that $50 \mathrm{mg} / \mathrm{L}$ cefotaxime and $25 \mathrm{mg} / \mathrm{L}$ cefotaxime plus streptomycin resulted in the best shooting performance as expressed in terms of mean number of shoots per explant and mean shoot length of the explants. Higher concentrations were not only less effective but also more toxic. Similar findings were reported with ginger [15]. The yellowing of microshoots observed in our study was also reported elsewhere [41]. Interestingly, the microshoots turned green and grew normal upon sub-culturing. Some researchers have formulated an effective cocktail of antibiotics comprising of erythromycin, streptomycin, carbenicillin, penicillin, streptomycin, amphotericin $\mathrm{B}$, and $\mathrm{NaOCl}$ that was effective in controlling contamination but failed to satisfy the nonphytotoxic criterion [45]. This implies that formulations that can effectively control contaminations are not always suitable in enhancing micropropagation.

\section{Concluding Remarks}

Ginger is one of the most important global commodities that bring millions of dollars in revenue to many countries of the world including Ethiopia. The Ethiopian ginger cultivar Deribo possesses some qualities that made it more preferred in the European market. The variety is cultivated by small- 
scale farmers in many parts of southern and western Ethiopia with no inputs of advanced technology and scientific agronomic practices. This led to the devastation of the ginger growing areas by the introduction and spread of ginger wilt bacteria since 2014. The adoption of relevant knowledge and technology for mitigating the problem and promoting the sector is long overdue. This paper presented the results of a scientific exercise aiming at developing protocols of sterilizing ginger shoot tip explants and controlling bacterial contamination of in vitro ginger micropropagation media. The exercise yielded outstanding results towards developing an optimized and refined in vitro micropropagation protocol of the Deribo ginger cultivar. Future studies need to aim at establishing the best procedure of sterilizing ginger shoot tip explants and controlling bacterial contaminants of the explants and in vitro micropropagation media with minimum or no phytotoxicity to the explants and plantlets generated by the micropropagation process. Many more antibiotics and combinations have to be tested in search of less or nonphytotoxic formulations.

\section{Data Availability}

The datasets used and/or analyzed during the current study are available from the first author on reasonable request.

\section{Conflicts of Interest}

The authors declare no conflicts of interest.

\section{Acknowledgments}

The authors acknowledge the Tigrai Biotechnology Center Pvt. Ltd. Co. for funding and hosting the research.

\section{References}

[1] D. Heller, "Annales des Sciences Naturelles," Botaniqueet Biologie ve'ge'tale, vol. 14, pp. 1-223, 1953.

[2] T. Fikre and A. Kifle, Ginger (Zingiber officinale Rosc.): Production, Postharvest Handling, Processing and Marketing: A Comprehensive Extension Package Manual, Farm Africa, Addis Ababa, Ethiopia, 2013.

[3] D. David, T. Y. Ji, and J. A. Gansau, "In vitro propagation of Zingiber officinale Rosc. "Tambunan"” Transactions on Science and Technology, vol. 3, no. 1-2, pp. 162-167, 2016.

[4] Y. Wagesho and B. S. Chandravanshi, "Levels of essential and non-essential metals in ginger (Zingiber officinale) cultivated in Ethiopia," SpringerPlus, vol. 4, no. 1, p. 107, 2015.

[5] M. S. Abbas, H. S. Taha, U. I. Aly, H. M. El-Shabrawi, and E.-S. I. Gaber, "In vitro propagation of ginger (Zingiber officinale Rosco)," Journal of Genetic Engineering and Biotechnology, vol. 9, no. 2, pp. 165-172, 2011.

[6] R. C. Hiremath, "Micropropagation of ginger (zingiber officinale rosc.)," Unpublished Doctoral Dissertation, University of Agricultural Sciences, Dharwad, Karnataka, 2006.

[7] J. S. Pruthi, Major Spices of India: Crop Management PostHarvest Technology, Indian Council of Agricultural Research, New Delhi, India, 1998.

[8] H. M. Girma and T. Degafe, "Registration of plant varieties," Ethiopian Journal of Agricultural Sciences, vol. 21, no. 1-2, pp. 179-194, 2011.
[9] H. Vijayalaxmi and H. Sreepada, "An economic overview of ginger production in Ethiopia," International Journal of Science and Research, vol. 3, no. 12, pp. 2052-2054, 2014.

[10] G. Endrias and K. Asfaw, "Production, processing and marketing of ginger in Southern Ethiopia," Journal of Horticulture and Forestry, vol. 3, no. 7, pp. 207-213, 2011.

[11] K. Bekelle, K. Habetewold, H. Tariku, and S. Kasahun, "Status of ginger wilt and identification of the causal organism in southern Nations nationality and people state of Ethiopia," International Journal of Research Studies in Agricultural Sciences, vol. 2, no. 4, pp. 1-11, 2016.

[12] S. Herms, "Investment opportunities in the Ethiopian spice sub-sector," in The Series Written for the Ethiopian Netherlands Business Event, Business Opportunities Report Spices, Rijswijk, The Netherlands, 2015.

[13] B. Ayenew, W. Tefera, and B. Kassahun, "In vitro propagation of Ethiopian ginger (Zingiber officinale Rosc.) cultivars: evaluation of explant types and hormone combinations," African Journal of Biotechnology, vol. 11, no. 16, pp. 39113918, 2012.

[14] D. E. Stead, "Identification of bacteria by computer-assisted fatty acid profiling," Acta Horticulturae, vol. 225, no. 225, pp. 39-46, 1988.

[15] A. Jain, K. Aravindaram, and D. Pal, "Molecular identification and antibiotic control of bacterial contamination in cultures of ginger (Zingiber officinale)," The Journal of Horticultural Science and Biotechnology, vol. 91, no. 2, pp. 122-128, 2016.

[16] S. Kavita, S. Saxena, A. Anand, and M. Lal, "Use of antibiotics to control bacterial contamination during in vitro micropropagation of sugarcane," Agrica, vol. 4, no. 1, pp. 41-44, 2015.

[17] J.-Y. Fang and Y.-R. Hsu, "Molecular identification and antibiotic control of endophytic bacterial contaminants from micropropagated Aglaonema cultures," Plant Cell, Tissue and Organ Culture (PCTOC), vol. 110, no. 1, pp. 53-62, 2012.

[18] R. B. Amgai, H. K. Prasai, and Y. R. Pandey, "Effect of sucrose and growth regulator's level on ginger micropropagation," Journal of Nepal Agricultural Research Council, vol. 3, pp. 45-48, 2017.

[19] A. R. Zuraida, S. M. A. Mohd, S. M. N. Erny et al., "Micropropagation of ginger (Zingiber officinale var. rubrum) using buds from microshoots," Pakistan Journal Botany, vol. 48, no. 3, pp. 1153-1158, 2016.

[20] R. Kavyashree, "An efficient in vitro protocol for clonal multiplication of Ginger-var, Varada," Indian Journal Biotechnology, vol. 18, pp. 328-331, 2009.

[21] R. T. Faria and R. D. Illg, "Micropropagation of Zingiber spectabile griff," Scientia Horticulturae, vol. 62, no. 1-2, pp. 135-137, 1995.

[22] T. Murashige and F. Skoog, "A revised medium for rapid growth and bio assays with tobacco tissue cultures," Physiologia Plantarum, vol. 15, no. 3, pp. 473-497, 1962.

[23] H. B. Abraha, D. B. Sbhatu, and M. Muthuswamy, "In-vitro micropropagation of A. percrassa Tod," Asian Journal of Plant Science, vol. 13, no. 2, pp. 66-72, 2014.

[24] M. Yifter, D. B. Sbhatu, F. Mekbib, and E. Abraha, "In vitro regeneration of four Ethiopian varieties of sesame (Sesamum indicum L.) using anther culture," Asian Journal of Plant Sciences, vol. 12, no. 5, pp. 214-218, 2013.

[25] C. Jayakrishna, C. Karthik, S. Barathi, D. Kamalanathan, and I. P. Arulselvi, "In vitro propagation of Aloe barbadensis Miller: a miracle herb," Research in Plant Biology, vol. 1, no. 5, pp. 22-26, 2011. 
[26] E. T. Oliveira, O. J. Crocomo, T. B. Farinha, and L. A. Gallo, "Large-scale micropropagation of Aloe vera," Hortscience, vol. 44, pp. 1675-1678, 2009.

[27] V. M. Loyola-Vargas and F. Vazquez-Flota, Methods in Molecular Biology: Plant Cell Culture Protocols, Humana Press, Totowa, NJ, USA, 2006.

[28] D. Aggarwal and K. S. Barna, "Tissue culture propagation of elite plant of aloe vera linn." Journal of Plant Biochemistry and Biotechnology, vol. 13, no. 1, pp. 77-79, 2004.

[29] M. M. Khatun, T. Tanny, M. Abdurazzak et al., "Standardization of in vitro sterilization procedures for micropropagation of ginger (Zingiber officinale Rosc.)," International Journal of Applied Biology and Pharmaceutical Technology, vol. 7, no. 1, pp. 131-137, 2016.

[30] B. Suma, R. Keshavachandran, and E. V. Nybe, "Agrobacterium tumefaciens mediated transformation and regeneration of ginger (Zingiber officinale Rosc.)," Journal of Tropical Agriculture, vol. 46, no. 1-2, pp. 38-44, 2008.

[31] I. Mihaljevic, K. Dugalic, V. Tomaš et al., "In vitro sterilization procedures for micropropagation of "oblacinska" sour cherry," Journal of Agricultural Sciences, Belgrade, vol. 58, no. 2, pp. 117-126, 2013.

[32] K. H. Nongalleima, S. T. Dikash, A. Dey, D. Lokesh, and D. H. Sunitibala, "Optimization of surface sterilization protocol, induction of axillary shoots regeneration in Zingiber zerumbet (L.) Sm. as affected by season," Biological Rhythm Research, vol. 45, no. 2, pp. 1-8, 2013.

[33] K. E. Danso, E. Azu, W. Elegba, A. Asumeng, H. M. Amoatey, and G. Y. P. Klu, "Effective decontamination and subsequent plantlet regeneration of sugarcane (Sacchrum officinarum L.) in vitro," International Journal of Integrated Biology, vol. 11, pp. 90-96, 2011.

[34] A. M. Eed, S. A. Reddy, K. M. Reddy et al., "Effects of antibiotics and fungicides on the in vitro production of Citrus limona Osbek nodal segment and shoot tip explants," The Asian and Australasian of Plant Science and Biotechnology, vol. 4, no. 1, pp. 66-70, 2010.

[35] F. Altan, B. Bürün, and N. Sahin, "Fungal contaminants observed during micropropagation of Lilium candidum L. and the effect of chemotherapeutic substances applied after sterilization," African Journal of Biotechnology, vol. 7, pp. 991-995, 2010.

[36] P. G. Sohnle, B. L. Hahn, T. A. Fassel, and V. M. Kushnaryov, "Analysis of fluconazole effect on Candida albicans viability during extended incubations," Medical Mycology, vol. 36, no. 1, pp. 29-36, 1998.

[37] B. Mengs, "Control of contamination and explants phenolics in ginger accession (Zingiber officinale Rosc.) in vitro cultures," Journal of Biology, Agriculture and Healthcare, vol. 8, no. 13 , pp. $54-58,2018$.

[38] S. S. Ray and N. Ali, "Biotic contamination and possible ways of sterilization: a review with reference to bamboo micropropagation," Brazilian Archives Biology and Technology, vol. 59, Article ID e160485, 2016.

[39] T. Orlikowska, P. Sobiczewski, M. Zawadzka, and E. Zenkteler, "The control and eradication of bacterial infections and contaminations in plant tissue culture," Biotechnologia, vol. 2, no. 89, pp. 57-71, 2010.

[40] T. Orlikowska and M. B. Zawadzka, "Bacteria in plant tissue culture (Abstract)," Biotechnologia, vol. 4, no. 75, pp. 64-77, 2006.

[41] A. Wojtania, J. Puławska, and E. Gabryszewska, "Identification and elimination of bacterial contaminants from
Pelargonium tissue cultures," Journal of Fruit and Ornamental Plant Research, vol. 13, pp. 101-108, 2005.

[42] P. M. Buckley, T. N. Dewilde, and B. M. Reed, "Characterization and identification of bacteria isolated from micropropagated mint plants," In Vitro Cellular \& Developmental Biology-Plant, vol. 31, no. 1, pp. 58-64, 1995.

[43] C. Leifert, B. Waites, J. W. Keetley, S. M. Wright, J. R. Nicholas, and W. M. Waites, "Effect of medlium acidification on filamentous fungi, yeasts and bacterial contaminats inDelphinium tissue cultures," Plant Cell, Tissue and Organ Culture, vol. 36, no. 2, pp. 149-155, 1994.

[44] J. E. A. Seabrook and G. Farrell, "City water can contaminate tissue culture stock plants," HortScience, vol. 28, no. 6, pp. 628-629, 1993.

[45] E. I. Mbah and S. M. Wakil, "Elimination of bacteria from in vitro yam tissue cultures using antibiotics," Journal of Plant Pathology, vol. 94, no. 1, pp. 53-58, 2012.

[46] M. J. Jamsheera, S. Vivas, M. C. Shiji, K. Resiya, and B. T. Umesh, "An efficient protocol for raising contamination free micropropagation of Zingiber officinale (Ginger)," Journal Pharmaceutical and Biological Sciences, vol. 4, no. 5, pp. 145-148, 2016.

[47] A. A. Kulkarni, S. M. Kelkar, M. G. Watve, and K. V. Krishnamurthy, "Characterization and control of endophytic bacterial contaminants in in vitro cultures of Piper spp., Taxus baccata subsp. wallichiana, and Withania somnifera," Canadian Journal of Microbiology, vol. 53, no. 1, pp. 63-74, 2007.

[48] H. K. Nadha, R. Salwan, R. C. Kasana, M. Anand, and A. Sood, "Identification and elimination of bacterial contamination during in vitro propagation of Guadua angustifolia Kunth," Pharmacognosy Magazine, vol. 8, no. 30, pp. 93-97, 2012. 